\title{
Victim Rhetoric among Sex Offenders: A Case Study of the Former Israeli President
}

\author{
Efrat Shoham ${ }^{1}$ \\ ${ }^{1}$ Criminology departement', Ashkelon Academic Collage, Ashkelon, Israel \\ Correspondence: Efrat Shoham, Criminology Depatment ,12 Yitzhak Ben-Zvi St., Ashkelon 78211, Israel. Tel: \\ 5-2232-7395; 8-678-9111; 8-679-0840. E-mail: shoham@netzer.org.il
}

Received: November 4, 2014 Accepted: November 15, $2014 \quad$ Online Published: February 13, 2015

doi:10.5539/jpl.v8n1p26 URL: http://dx.doi.org/10.5539/jpl.v8n1p26

\begin{abstract}
In 2009, the Israeli eight former president Katzav was accused of two counts of rape against an employee working under his authority during his time as Minister of Tourism. The story of the conviction of the eighth Israeli president of sex offences turned into a high-priority media story, which stayed at the top of the Israeli media agenda for a relatively long period.

This qualitative paper, is aiming to identify and analyze the various rhetorical techniques utilized by Katsav, to replace the new criminal identity attributed to him with a victimized self-identity. The victimized rhetoric which is based on justifications and accounts such as: "Reverse character assassination", "Attack the attackers" or "Contradiction technique", had served the former president as a means to reduce his responsibility, to deny it and to build an alternative narrative that presents the alleged perpetrator as a persecuted victim. Never the less, the conviction and jailing of a president for sex crimes has greatly increased the awareness of sex offences in the workplace committed by people of power and authority.
\end{abstract}

Keywords: sex offences, victim rhetoric, Israel

\section{Introduction}

One of the most interesting aspects of the study of criminal behavior is that of the criminal or victim identity structure and rhetoric, which accompanies these processes. In their cutting-edge study, Sykes and Matza (1957) argued that a significant part of criminal activity is accompanied by a criminal's justifications for his own deviant behavior. These justifications aim to replace or reduce the power of being branded a criminal by the law enforcement system and the criminal's environment, and to protect him from feelings of guilt and shame. Sykes and Matza defined these justifications via the psychoanalytical terminology, which was becoming popular at the time, combined with criminological explanations such as projection, rationalization and denial - i.e. explaining them as part of a person's subconscious defense mechanisms.

The combination of mechanisms is designed to permit a person to believe that, although he committed a crime, he is not a bad person since he can provide himself and others with a valid, convincing explanation for his unacceptable behavior. This combination, which Sykes and Matza termed "neutralization techniques", serves people who carried out acts that are perceived as 'bad' or 'prohibited' in five main areas: denial of responsibility (the criminal act was the result of powers beyond his control: "what could I do?"); denial of injury (minimizing the damage caused to people or property, e.g. a car thief refers to his actions as "borrowing" and a vandal refers to his actions as a "trick" or "prank"); denying the victim (who is turned into a person who "should" be hurt, e.g. "he started it"); denouncing the defenders ("police, teachers and law-makers are a hypocritical, corrupt, stupid and brutal bunch", "the victim is lying") and finally, a willingness to follow the rules of higher loyalties (such as religious orders, a gang, organization, family, friendship, etc.).

Building on Sykes and Matza's neutralization techniques (1957), Scott and Lyman (1968) added the term of "justifications". Justifications are verbal means that a person utilizes to present a different interpretation than that which would define his actions or himself as deviant. Scott and Lyman differentiate between excuses and justifications. When a person makes excuses, he admits that his behavior was wrong, but does not take responsibility for its consequences. When justifying, a person accepts responsibility but rejects the negative interpretation attributed to his actions. However, the option of using different types of excuses and justifications 
is not equally available to different people; when people are defined by society as deviant, their right to credibility is revoked, and so in many cases they cannot rehabilitate the symbolic representation of their position (Timor, 1996). The analysis of how justifications and excuses are presented helps determine the way in which a person structures a social identity and struggles against negative labeling. In many cases, this struggle involves constructing a future self-identity that will replace the familiar but stained identity (Abulafia, 2005).

Scully and Marolla (1984) have investigated the use of neutralization techniques in the context of the struggle experienced by rapists with the stigmas attached to them. They examined the rich vocabulary and expressions that rapists used to justify their behavior by constructing an image of a "good guy", which allows a rapist to admit his mistake and at the same time maintain the claim that, in general, he is no different from "regular" people (as demonstrated later in this paper, in the story of former Israeli President, Moshe Katsav). Buzzell (2005) also mentions several additional techniques of reducing a rapist's responsibility for their victim's agony:

- Using metaphors borrowed from taxes evasion terminology: "I did what I did, that's true, but at the end of the day I'm a law-biding citizen".

- The rhetoric of denial based on a claim that the behavior is normal. This technique enables the denial of negative components of the behavior based on the innuendo that "everyone does it".

- Denying the negative intention behind the act and presenting it as an innocent gesture that did not mean to cause any harm. This technique depicts others as causing much more severe insults and damage.

This paper will discuss the case of the Eighth President of Israel, Moshe Katsav, who was convicted of rape and sentenced to a prison term. The paper analyzes the various techniques through which the convicted president tried to restructure his self-identity as a victim instead of a criminal. This process, referred to by Holstein and Miller (1993) as the "Victim Contest", is a rhetorical process intended to confer a positive label onto an individual, based on a new self-identity of a victim. This process is contrary to another rhetorical process termed the "Stigma Contest", whose purpose is to substitute an individual's normative identity with that of the new criminal identity attributed to him. According to Holstein and Miller's approach, structuring a victimized self-identity is based on the Rhetoric of Victimization, which allows a person to construct a subjective identity of a victim in his own eyes, or struggle against the normative definition of his society.

\subsection{A Culture of Denial}

Cohen (2001) explains that denying violent events portrayed in the mass media is based on what he referred to as the "spiral of denial". The denier's preliminary reaction is to deny the event by presenting it as something strange, irrational or impossible (explicit denial). When the facts concerning the event become clear and can no longer be denied, the denier will deny other elements of the story or give a response that rearranges the order of actions in the story (interpretative denial). When this technique become inefficient, the third step of denial is reached, in which the denier admits the description of the facts and their order of occurrence, but denies the guilt and responsibility through denying of the victim or damage ("indeed there was a use of force and a violent act, but they were directed towards a dangerous person trying to harm me").

Cohen describes a process of explicit denial by bystanders, which is characterized by the perception that there is no real suffering behind the story as it is told ("this could not happen without us knowing about it" or "we didn't notice anything"). Through it, he expands his analysis of interpretative denial, which is based on attributing different meanings to the events (declarations such as "trafficked women are not victims, they are escorts, sex workers, models"; "violence against women or children is a personal problem", "it's the result of mental illness", "it was a sporadic event, a one-off failure"; "it was the behavior of marginal sub-cultures").

The process of structuring specific social problems is tightly bound up in the cultural system and the politics of representations that operate within it (Shoham \& Doron, in press). Each society has its own characteristic organizational forms of legal, welfare and health systems, of political cultures derived from the balance between religious and secular groups, ethnic relations, etc. (Misztal \& Moss, 1990). The form of speech and phrasing used by a speaker who is obliged to promote discourse regarding new social problems greatly depends on the way that people (and their audience - the public, the media, and the policy makers) habitually talk about other familiar issues (Best, 1999:164). Presenting arguments includes declaring problems worth fighting for or issues that should gain society's attention (Furedi, 2004: 176). An examination of local cultural resources exposes these patterns and the characteristic expressions, motifs, styles, models and frameworks that give rise to a rhetoric that is unique to a local culture (Best, 1999: 87-88). Structuring different issues as a "social problem" and denial of other social issues is usually carried out through means of mass media. 


\subsection{Media Coverage of Rape}

The way that rape is presented in the mass media tends to be stereotypical, sensational and exceptional (Soothill \& Walby, 1991; Korn \& Efrat, 2004). The description of sexual violence in the media stems from a series of myths regarding this act, its causes and participants. Benedict (1992) mentions as an example that media descriptions of rape tend to fit the raped woman into one of two main stereotypes: either she was a naïve virgin who was attacked by a monstrous and devious stranger, or a promiscuous woman who, through her behavior or appearance, brought the attack on herself. These two patterns perpetuate the perception that women can be either Madonnas or Whores. It is possible that it is exactly this dramatization of sexual violence by the media and the structuring of news reports into dichotomous and stereotypical patterns that distances structural explanation for these assaults and silences discussion of much wider subjects regarding power and gender issues (Cuklanz, 2000).

The stories that the mass media chooses to cover as part of their process of structuring social problems creates an effect and leaves a legacy of opinions, beliefs and worldviews (Cavaglion \& Shoham, 2012). For example, media coverage in Israel during the late 1980s of the sexual assault of the child Moran Nachmias and her manslaughter accelerated the coming into force of a law stipulating the public's obligation to report harm caused to children and increasing the punishment for incest. In this case, the media was unwilling to cease coverage of this story for weeks. For the first time, it did not exhibit "tiredness" and frustration over repeated coverage ("child abuse fatigue", see the discussion in Ajzenstadt \& Cavaglion, 2004). The same phenomenon was seen in the media coverage of the rape and murder of seven-year-old Megan Kanka in the United States in 1994, which led to a series of laws called "the Megan Laws", aimed to limit sex offenders and supervise them even after they finished serving their sentences. Shoham (2008) argues that the media moral panic that repeatedly occurred during the past ten years in Israel regarding sex offenders was one of the main causes that led to the amendment of legalization towards increased supervision, limitation and prohibitions applied to people who are defined as sex offenders, even when they are in the community (for a parallel discussion in Britain, see Greer, 2003: 59).

According to Critcher (2006: 134), certain definitions of problems and social issues are more prominent in the public discourse since they define the parameters of the controversy between social agents. Hall et al (Hall, Critcher \& Jefferson, 1978) term these social agents as "primary definers", the most conspicuous of which are representatives of the state and legal systems, professionals and police officers. These are the reliable and formal sources that possess sufficient power to provide the "facts" to the media (Greer, 2003: 13).

In addition to the symbiotic state in which media works with various governmental systems, the media is able to produce real or fictional news dramas on its own. One of the most outstanding examples of this is the relationship between crime and the media, a subject that has been debated for dozens of years, with the argument that a superficial media culture constantly erodes moral standards. In this context, social deviance and crime in particular are perceived as a type of entertainment in the form of "police shows": television series, crime dramas, documentaries of staged reality shows, editorials, etc. (Garland \& Bilby, 2011; Littlefield, 2011). This pattern makes it even harder to differentiate between factual and fictional reality. The rising popularity of television reality shows emphasizes the confusion between reality, fiction and entertainment.

Apart from newsroom priorities regarding what is newsworthy, some researchers claim that the fact that events are criminal automatically makes them newsworthy, be it as headlines or prime news, especially if the events in question also have links to entertainment, voyeurism and sex (Greer, 2003: 100). Chibnall identifies eight "professional directives" that guide the creation of news items and which explain the importance of dealing with crime news: immediacy and attraction (the story must be attractive to the viewing audience), dramatization, innovation, titillation (even sexual), adherences to the mainstream and hegemonic ideology, simplicity (good vs. evil), visibility (including by using graphic descriptions) and personalization (e.g. greater relevance when events involve celebrities or characters that are familiar and close, even geographically, to the reader/viewer audience) (Chibnall, 1977: 23).

Jewkes (2004) demonstrates that one can positively or negatively interpret the means used by the media to form ideas, values, opinions and behaviors, all according to the readers' worldview. We expect, and perhaps assume, that the media will present the facts related to the event as is and describe the general crime scene, however this is hardly the case. Therefore, even though the media are often referred to as the "window to the world" and allegedly reflect real life, it is more accurate to say that the media express feelings filtered through a prism that exposes that part of the world which a specific media organization chooses to publish, sometimes distortedly.

Another element that molds the production of news is the media decision makers' evaluation of the depth of emotions that will be experienced by difference audiences. This evaluation leads to a selection of new topics and 
preference is given to certain stories over others. The process and the editing that it entails, including the use of specific words, images and graphics, define the tone of the story, and are referred to as "setting an agenda" or "framing the news". This process is first conducted in the newsroom, where a few events are selected out of thousands of daily happenings. The interpretation of these events produces a relationship between certain sectors of society and particular behaviors, and so reinforces the logic and common popular perceptions regarding the causes of the problem and the types of solutions suggested for these selected issues (Cavaglion \& Shoham, 2012)

\section{A Case Study: The Story of a President Convicted of a Sex Offence}

It is uncommon for a case of violence towards women to turn into a media story that does not leave the media agenda for a long time. This is, however, the story in the case of the eighth Israeli President, Moshe Katsav, who was convicted of rape. A story becomes a media story when there are important people or institutions involved who possess great power and influence over society (Harcup \& O'Neill, 2011), and indeed the story of the conviction of the eighth Israeli president of sex offences turned into a high-priority media story, which stayed at the top of the media agenda for a relatively long period.

This qualitative paper, is aiming to identify and analyze the various rhetorical techniques utilized by Katsav, to replace the social criminal identity attributed to him with a victimized self-identity.

\subsection{The Legal Framing of the Case}

On March 19, 2009, the Israeli State Attorney, following an investigation characterized by twists and turns, filed an indictment against former president Katsav in which his was accused of two counts of rape against an employee working under his authority during his time as Minister of Tourism. In addition he was accused of counts of indecent assault, sexual harassment and disruption of proceedings.

After 64 court sessions documented in 7,792 pages of protocol and hundreds of exhibits presented to the court, Katsav was found guilty on the counts. The former president was sentenced to seven years in prison, two years of suspended sentence and ordered to pay compensation of 100,000 NIS to one of the victims. Unlike the way things usually occur in Israel, where a convicted sex offender manages his appeal from prison, the court allowed the former president's sentence to be postponed pending his appeal to the Supreme Court. His admittance to prison stimulated great interest and was often accompanied by wide media coverage at the center of which was an impassioned public discussion regarding whether or not a former president should be sent to prison as a punishment like any other criminal.

\subsection{The Media Framing of the Case}

The story of the conviction of the eighth Israeli president of serious sex offences was referred to by the media as the "Katsav Affair" and led to massive media preoccupation mainly with the testimonies of the plaintiffs, which snowballed due to the publication of the first plaintiff's testimony in the mass media. The media, which preoccupied itself with searching for dramatic labels that would clarify the public significance attributed to the matter, often switching the status of Katsav as a former president with legal terms that create primary labels, such as "suspect", "defendant", "convicted", "sex offender", "rapist" or "prisoner". For this end, the media mainly focused on events such as the dates of the filing of the indictment, the verdict and the sentencing. About a week before the indictment was filed, the former president called a press conference that was attended by senior $\mathrm{TV}$, radio and newspaper journalists, where he gave a speech of approximately three hours, which was later termed the "I accuse" speech.

In order to analyze Moshe Katsav's speech, it was recorded as broadcast on TV and transcribed. The analysis performed on the prime-time broadcast speech reveals several main uses of rhetoric aimed to allow the former president to construct himself as a victim.

\section{Findings}

\subsection{Reverse Character Assassination}

The former president chose to open his speech with the story of his family and political background, in which he depicts himself as a loving and decent family man, and tells of his great contribution and extensive work for the State of Israel. Katsav tells in detail of his good and important deeds through his political career and during his time as president, which he said benefitted the entire people of Israel, for the sake of Jewish values, for holocaust survivors, for the Arab population in Israel, for Israeli democratic values and for the soldiers of the IDF (Israeli Defense Force). Katsav goes on to describe how he managed his entire conduct out of a strong feeling of nationality, integrity and responsibility. This technique is based on the process which Cromer (1978) refers to as 
"reverse character assassination", and aims to create a separation and contradiction between one's past attributes, and the act he has been accused of. In order to win in the stigma contest and transform the tale of deviance into a rational one in the eyes of the audience, the story must create a state of consistency which can be adjusted to the accused person, his life story and the deviant act attributed to him (Lofland, 1969). At the beginning of his speech, Katsav wishes to breakdown the negative label conferred on him by creating distance, separation and miscorrelation between how he describes his contribution to his family and the people of Israel in the past, and the criminal actions he is accused of committing in the present.

\subsection{Attack the Attackers}

Later in his speech, Katsav uses the "Attack the Attackers" and "turning to a higher moral hierarchy" techniques, described by Sykes and Matza. Katsav often describes the law enforcement system via array of negative labels, which serve to question its capacity and moral and legal authority to provide a just trial, which is also why - he implies -- it should not be trusted regarding its accusations in his affair. Katsav describes the law-enforcement system as an irresponsible system, a ruthless system that employs street trials (...) a system that executes field trials (...). The presentation of the law-enforcement system as a failing one helps divert the discussion from the accusations made against him, which he completely denies and does not mention, towards the failures and omissions which are not only dangerous to the former president but may also put the entire existence of Israel at risk. To strengthen the existential threat of the law-enforcement system, Katsav compares it to an atom bomb that threatens all of us (...) malicious use of governmental power that may lead to the destruction of us all.

Katsav also refers to higher moral proceedings, which serve as substitutes for the corrupted mundane courts, the Almighty knows the truth. Using the technique of turning to higher morals and values, the speaker avoids confronting the unacceptable aspects of the crimes of which he has been accused. This technique also allows him to reverse his role: according to him, the true judge, the God of truth and justice knows that he is the good, haunted president and the system that persecutes and accuses him is corrupted and deviant.

\subsection{Contradiction Technique}

The contradiction technique allows one to create a dichotomy between good and evil, criminals and victims (Holstein \& Miller, 1990). While the president presents himself as a fair, honest, quiet, modest, law-abiding and polite person, the law enforcement system and mass media that serve as its accomplices are described as corrupt entities which occupy themselves day and night in brainwashing, incitement, attacking, persecuting, hatred and hostility. (...) these people drink my blood and wish to treat me like dirt, etc. This is a system that persecutes me out of hate, malice, double standards, hypocrisy, by tampering with and pressurizing witnesses.

By focusing on what he says is a mistake, incrimination or negligence, the former president can provide explanations or justifications for the negative state in which he finds himself (for the responsibility component of victimized rhetoric, cf. Levenson \& Macgowan, 2003; Scully \& Morolla, 1996).

\subsection{Sad Tale}

Katsav replaces the responsibility and guilt narrative with a story of persecution, misery and agony.

I stand before you, bleeding and crushed, the President of Israel was framed (...) everyone is looking for a way to hurt me (...) comb my body with iron combs.

The restructuring of his life story through a "sad tale" is designed to undermine the status of criminal and sex offender that has been attributed to him. Katsav's speech aims to create, through mass media, an alternative to his tale of deviance. This is the tale of a haunted, tragic anti-hero who completely denies the negative acts attributed to him and who wishes, through religious and historic metaphors, to create the narrative of a righteous and honest man, whose enemies have risen against him to murder him. Katsav makes a parallel between the story of Rabbi Akiva, one of the greatest sages of ancient Israel who was persecuted for his high position in biblical scripts by the Romans who controlled the area, and his own story, that of a former president who is being persecuted in his own country by the government authorities and the mass media that serve as its accomplices.

\section{Discussion}

Katsav's complete disregard for the facts of the accusations at hand and his focus on his great contribution to all sectors and minorities of Israeli society prevents the formation of a consistent narrative bridging his past, and the despised criminal act he was accused of perpetrating.

The use of the "innocence dramatization" attributed to the suspect, in contrast to the "malice dramatization" attributed to the systems that persecute him, allows the former president to deny the deviant components of his act and the label of criminal attributed to him, by adopting the label of victim that he attributes to himself. By 
refusing to take full responsibility for his actions the president reinforces the victimized rhetoric he uses. Casting the entire responsibility onto government authorities and the law enforcement system allows a person, according to Holstein and Miller (1993), to reinforce the victimized infrastructure of his self-identity.

To increase the validity and credibility of his tale, the former president turns to Jewish history and tales of heroism. By turning to something familiar, traditional and admired, and framing his personal story in terms of the tales of persecution against Jews throughout the course of history, the former president creates a cultural resonance that turns his story to a logical and acceptable one (for the role of cultural resonance in structuring one's personal or social story, see Shoham 2012).

The foundations for constructing a victimized self-identity can be found in the former president's story as early as eighteen months prior to his speech. From the moment the "Katsav Affair" was released to the press until the indictment was filed three years later, the voice of the plaintiffs was unheard in the media. These plaintiffs, whose position in Israel's legal system is that of a prosecution witnesses (Shoham \& Gideon, 2014), could not and perhaps would not expose themselves in the media and provide their versions. With their voices silenced, the plaintiffs' near total opacity only deepened the Katsav's construction of a victimized self-identity and formation of himself as a "persecuted character". If in the beginning of the process Katsav aimed his words to the specific women who testified against him to the police, as time passed the former president's "persecuted character" narrative turned to a master narrative which guided his relations with the mass media and the entire law-enforcement system. Constructing the persecuted label reached its peak in the speech referred to as the "Rage Speech".

Before the indictment was filed, the former president called a press conference in the president's residence and launched a callous and frontal attack against the media, who according to him undertook the role of investigators and judges, and which had convicted him without checking the facts, had hurt him, were slandering his reputation and spilling his blood. During this speech, the former president attempted to prepare the ground for the reversal of roles and complete denial of his deviant acts by attributing these acts to the plaintiffs. This practice of blaming the victim, according to Negbi (2009), often characterizes accusations of rape presented in Israeli courts and it focuses on passing responsibility to the complainants. In the "Rage Speech", the complainants were presented as liars, extortionists; as jealous, demented, manipulative and provocative women; women whose morals, credibility, authenticity and perhaps even mental fitness should be questioned. Convicted rapists often justify their behavior by denying the existence of an actual victim and by presenting the complainant as a seductive or guilty woman, utilizing the common stereotype of "good girls do not get raped" (Scully \& Marolla, 1996; Korn \& Efrat, 2004; Shoham, 2012b).

\section{Summary and Conclusion}

In his "I accuse" speech, former Israeli president Moshe Katsav does not refer to any of the counts in the indictment filed against him, but focuses on the injustice and harm brought upon himself and his family, according to him. This victimized rhetoric, which is based on justifications and accounts, serves as a means to reduce his responsibility, to deny it and to build an alternative narrative that presents the alleged perpetrator as a persecuted victim.

The entire speech was based on "victimized rhetoric", which is designed to undermine the deviant label that the State Attorney and media attributed to the former president, and to replace it with the narrative of a man who is being persecuted by different groups in Israeli society, such as women's organizations, the elite, Ashkenazi Jews, the State Attorney and the police, whom he said wished to spill his blood for no fault of his own, based solely on political, social and cultural reasons. Constructing a new self-identity of a victim that aims to replace the previous, negative identity of a criminal, is based on a "completing opposites" approach, whose purpose is to undermine the criminal label, to present its weaknesses and to reproduce a label with positive connotation of an injured person, a persecuted individual or a victim (Abulafia, 2005).

One of the most interesting questions that arise from the analysis of Katsav's "I accuse" speech, who was convicted of raping female subordinates was, whether these denial techniques really succeeded in creating a victimized identity in the eye of the public?

Katsav, the former president and a currently convicted sex offender, could not elevate his persecuted victimized label in the face of the flood unleashed by the media and public. Both tasted the power that allows one to topple presidents and transform those at the top of the governmental chain into deviants that must be hunted and excluded from society, and they were not about to give it up. One must remember that denial techniques are only efficient as long as the leader of the discourse represents dominant or powerful opinions; if the leader of the discourse belongs to a weakened group or is weakened due to the reversal of statuses, this technique loses its 
power.

The recruitment of traditional and new media to construct the deviant label and that of a sex offender made the use of various denial techniques inefficient. The great success of the process of redefining Katsav as a convicted sex criminal was based on the same practice of "reverse character assassination" (Cromer, 1978), in which in fact, it is the high position of the president and his success in Israeli politics that demonstrated and strengthened the volume of his deviance.

The label of sex offender, once gained, guides the attitudes and behaviors of others towards that person. This reconstruction of reality is the product of bargaining process (Scheff, 2009) between the person defined retrospectively as a deviant through the correlation of the dominant status of a deviant and his former life story, and between the people who wishes to use his prior life story to negate the label of deviant.

The process of lowering one's status (Fusfied, 1981) and replacing it with the dominant status of an unreliable philanderer and, worst of all, a sex offender, have led to the loss of legitimacy attributed by the a large part of the public to Katsav's version or the denial techniques he tried to use. The main label of a sex offender, attributed to the former president, has obliterated all of the other labels he used in an attempt to repel the image of himself as a criminal deviant.

Injures against women range through a wide spectrum of behaviors, from negligence, through sexual harassment and psychological abuse, as well as verbal, sexual, financial and emotional violence. The public, legal and communicative awareness of injures against women in the public or private spheres, oscillates between waves of awareness and concern to lack of comment or minimization and denial of the problem.

There are issues that are given greater attention and visibility in the media, such as violence towards women perpetrated by men of a high socio-economic status, and there are other affairs that are almost completely silenced (Shoham, 2012). Issues such as honor killings (Chesler, 2010; Shalhoub-Kevorkian, 2004), verbal, emotional or sexual violence towards female partners, forced prostitution of young women, and the trafficking of women who are not considered part of the "good" women population "worthy" of public protection, are not perceived as matters of public interest by the media and general public.

Media coverage of violence against women is often, according to Lemish (2007), a double-edged sword. On the one hand, the media's preoccupation with cases of extreme physical violence (especially those ending with a woman's murder) has contributed greatly to putting these issues on the public's agenda and positioning them as a main problem whose debate, treatment and consequences must be promoted. This has led to significant social change in the way the law enforcement system operates. On the other hand, the focus in violence towards women is merely a part of a trend that depicts women as victims or relatives of victims, a trend which continues to fixate on women's social inferiority as society members, and as those who need protecting and rescuing by males-dominated systems.

It could be argued that, much like the debate regarding celebrity victims of rape (Shoham, 2012b), that in the case of celebrity criminals such as the former president the attention and media occupation is focused on the criminal's subjective characteristics and much less attention is directed to the cultural, political and social meaning of the phenomenon of sex offences against women in the workplace. However, it seems that in Israel, the conviction and jailing of a president for sex crimes has greatly increased the awareness of sex offences in the workplace committed by people of power and authority, which led to a significant increase in the filing of indictments against individuals in senior positions in organizations such as the police, military, and other government offices.

\section{References}

Abulafia, J. (2005). The social construction of victimization among prisoners. Dissertation work for PhD, submitted to the Criminology Department. Ramat Gan: Bar-Ilan University. (Hebrew).

Ajzenstadt, M., \& Cavaglion, G. (2004). Sociological perspectives on the origins of child abuse legislation in Israel. Israel Law Review, 37, 169-196.

Benedict, H. (1992). Virgin or vamp: How the press covers sex crimes. Oxford: Oxford University Press.

Bennett, T. (1982). Media reality signification. In M. Gurevitch, T. Bennett, J. Curran, \& J. Woollacott (Eds.), Culture, society and the media (pp. 287-308). London: Routledge.

Best, J. (1999). Random violence: How we talk about new crimes and new victims. Berkley: University of California Press.

Buzzell, T. (2005). The effects of sophistication, access and monitoring on use of Pornography in three 
technological contexts. Deviant Behavior, 26, 109-132. http://dx.doi.org/10.1080/01639620590518988

Cavaglion, G., \& Shoham, E. (2012). Cults, violence and sex: The social construction of deviance in Post-Modern Israel. N.Y.: Nova Publishers.

Chesler, P. (2010). Worldwide trends in honor killing. Middle East Quarterly, 3-11.

Chibnall, S. (1977). Law and order news. London: Tavistock.

Cohen, S. (2001). States of denial: Knowing about atrocities and suffering. Cambridge: Polity Press.

Critcher, C. (2006). Moral panics and the media. Maidenhead, UK: Open University Press.

Cromer G. (1978). Character assassination in the press. In C. Winick (Ed.), Deviance and mass media (pp. 225-241). London: Sage.

Cuklanz, L. M. (2000). Rape on prime time: Television, masculinity and sexual violence. Philadelphia: University of Pennsylvania Press.

Furedi, F. (2004). Therapy culture: Cultivating vulnerability in an uncertain age. New York: Routledge.

Garland, J., \& Bilby, C. (2011). 'What next, dwarves?': Images of police culture in life on mars. Crime, Media and Culture, 7, 115-132. http://dx.doi.org/10.1177/1741659011406701

Greer, C. (2003). Sex crime and the media: Sex offending and the press in a divided society. Cullompton, Devon, UK: Willan.

Gusfield, J. (1981). The culture of public problems. Chicago: The University of Chicago Press.

Hall, S., Critcher, C., \& Jefferson, T. (1978). Policing the crisis: Mugging, the state and laws and order. London: Macmillan Publication.

Harcup, T., \& O'Neill D. (2001). What is news? Galtung and ruge revisited. Journalism Studies, 2, 261-280. http://dx.doi.org/10.1080/14616700118449

Holstein, J., \& Miller, G. (1990). Rethinking victimization: An interactional approach to victimology. Symbolic Interaction, 13, 103-122. http://dx.doi.org/10.1525/si.1990.13.1.103

Jewkes, Y. (2004). Media and crime. London: Sage.

Koren, A., \& Efrat, S. (2004). The coverage of rape in the Israeli popular press. Violence against Women, 10, 1056-1074. http://dx.doi.org/10.1177/1077801204267378

Lemish, D. (2007). The politics of minority exclusion in the media: Women image and coverage of violence against them. In D. Caspi (Ed.), Communication and politics in Israel (pp. 185-207). Jerusalem and Tel-Aviv: van-Leer Jerusalem Institute: Hakibbutz Hameuchad Publishing. (Hebrew).

Levenson, J. S., \& Macgowan, M. J. (2004). Engagement, denial, and treatment progress among sex offenders in group therapy. Sexual abuse: Journal of research and treatment, 16, 49-63.

Littlefield, M. (2011). Historicizing CSI and its Effect(s): The real and the representational in American scientific detective fiction and print news media, 1902-1935. Crime, Media, Culture, 7, 133-148. http://dx.doi.org/10.1177/1741659011406700

Lofland, J. (1969). Deviance and identity. Englewood Cliffs, NJ: Prentice Hall.

Misztal, B., \& Moss, D. (Eds.). (1990). Action on AIDS: National policies in comparative perspective. New York: Greenwood.

Negbi, I. (2009). Rape stories in the court: narrative analysis of court rulings. Tel Aviv: Resling.

Orbuch, T. L. (1997). People's accounts count. The sociology of accounts. Annual Review of Sociology, 23, 478-455. http://dx.doi.org/10.1146/annurev.soc.23.1.455

Scheff, T. J. (2009). Being mentally ill: A sociological theory (3rd ed.). New Brunswick \& London: Aldine Transaction.

Scott, M., \& Lyman, S. (1969). Accounts. American Sociological Review, 31, 62-46.

Scully, D., \& Marolla, J. (1996). Convicted rapists' vocabulary of motive: Excuses and jJustifications. In P. Cromwell (Ed.), In their own words (pp. 107-116). Los Angeles, California: Roxbury Publishing Company.

Shaloub-Kevorkian, N. (2004). Imposition of virginity: Testing a life saver or a license to kill. Social Science and Medicine, 60, 1187-1196. http://dx.doi.org/10.1016/j.socscimed.2004.07.015 
Shoham, E. (2008). Supervision of sex offenders in Israel. Tel Aviv: Perlstein-Ginosar Publishing, Law Books Publishers. (Hebrew).

Shoham, E. (2012a). Peeking through the walls of violence towards female partners in closed communities. Beer Sheva: Ben-Gurion University in the Negev Publishing. (Hebrew).

Shoham, E. (2012b). Coverage of the rape of a "Celebrity Victim" by the Israeli daily press. International review of social sciences and humanities, 4(2), 108-117.

Shoham, E., \& Doron, S. (in press). Attitude towards the other in Israeli society: being over-exposure and transparency. Beer Sheva: Bialik Institute. (Hebrew).

Shoham, E., \& Gideon, L. (2014). Are crime victims being gagged under the Israeli criminal justice procedures? International journal of Criminology and Sociology, 3, 5-19.

Soothill, K., \& Walby, S. (1991). Sex crimes in the news. London: Routledge.

Sykes, G., \& Matza, D. (1957). Techniques of neutralization: A theory of delinquency. American Sociological Review, 22, 664-670. http://dx.doi.org/10.2307/2089195

Timor, U. (1996). Dealing with the past in Talmudic colleges that rehabilitate prisoners. Megamot, 30, 30-47. (Hebrew).

\section{Copyrights}

Copyright for this article is retained by the author(s), with first publication rights granted to the journal.

This is an open-access article distributed under the terms and conditions of the Creative Commons Attribution license (http://creativecommons.org/licenses/by/3.0/). 